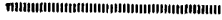 \\ 論 文 UDC $669.14 .018 .298 .2-15: 669.14 .018 .298 .2-122.2: 669.15^{\prime} 26-194:$

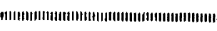 \\ $620.179 .5: 621.91 .011: 669.775: 669.4$ \\ Cr 肌焼鎆の切りくず処理性に及ぼす快削性元素, 熱処理組織および冷間加工の影響*
}

\author{
山本 俊 郎**.熊 谷 憲 一***
}

\section{Effects of Free-Cutting Additives, Heat-Treated Structures and Cold Working on the Machinability of Low Chromium Case- Hardening Steel Based on the Chip-Breaking Characteristics}

Toshiro Yamamoto and Ken-ichi Kumagayi

Synopsis:

Effects of free-cutting additives, heat-treated structures, and cold working on the machinability of low chromium case-hardening steels based on the chip-breaking characteristics have been investigated.

The order of free-cutting additives in decreasing contribution to a favourable broken chip were $\mathrm{Bi}>$ $\mathrm{Pb}>\mathrm{S}>\mathrm{Se}$ and $\mathrm{Te}$ at the same amount of addition in weight per cent. The effects of $\mathrm{P}$ and $\mathrm{N}$ on the contribution to a broken chip were comparatively small.

The machinability of case-hardening steels based on the chip-breaking characteristics was the best for spheroidized structure and decreased in the order of annealed structure to normalized structure. Cold working was detrimental to the machinability of spheroidized structure in terms of the chip-breaking characteristics.

The effects of heat-treated structures and cold working on the machinability based on the chip-breaking characteristics is mainly explained by the ratio of the chip thickness to the diameter of a helical chip, i.e., a high ratio provides a favourable broken chip.

\section{1. 緒言}

自動化，高速化された機械工場では，切りくず処理性 の良否は重要な被削性の評価基準である. 切りくず処理 を改善する方法として，良来よりチップブレーカーが広 く採用されているが1)，それのみでは切りくず処理が完 全に解決されない場合が多く，すぐれた切りくず処理性 が鋼材に要求されることになる.

切りくず処理性の改善および安定化という立場から は，仭削性元素の添加がもつとも効果的である. しかし 快削性元素の種類およびその添加量が切りくず処理性に およぼす影響は，現場作業における経験を通して知られ ている場合が多く，定量的に比較された研究は少ない2． また熱処理組織および冷間加工は被削材の延性および切 りくずの生成挙動に影響を及ぼし，切りくず処理性との 間に密接な関係を予想させる. しかし切りくず処理性と
熱処理組織および冷間加工との関係についても，切りく ず処理のトラブルを介して経験的に知られている面が多 W.

著者ら ${ }^{3)}$ は, 工具寿命およびドリル穿孔性が熱処理組 織および冷間加工によつて大きな影響を受けることを報 告した.これにひきつづき, 本研究では切りくず処理性 と快削性元素, 熱処理組織抢よび冷間加工との関係を明 らかにせんと試みた。

\section{2. 試}

料

試料はA，BおよびCの 3 系列からなる. Table 1 に それらの化学組成を示した. A 系列の試料はJIS, SCr22 (その $\mathrm{S}$ 量は $0.011 \%$ )およびその化学組成に $\mathrm{S} 0.035$, $0.05,010$ および $0.20 \%, \mathrm{~Pb}$ を $0.05,0.10,0.15$, および $0.20 \%, \mathrm{Bi}$ を $0.05 \%, \mathrm{Se}, \mathrm{Te}$ および $\mathrm{P} を$ $0.10 \% ， \mathrm{~N}$ を $0.02 \%$ 目標に添加した14種の鋼である.

* 昭和 46 年 10 月本会㨾演大会にて発表 昭和 50 年 3 月 31 日受付 (Received March 31, 1975)

** 愛知製鋼 (株) 工博 (Aichi Steel Works, Ltd., 1 Wanowari, Araochō, Tokai 476)

****. 愛知製鋼 (株) (Aichi Steel Works, Ltd.) 
Table 1. Chemical compositions of steels (\%).

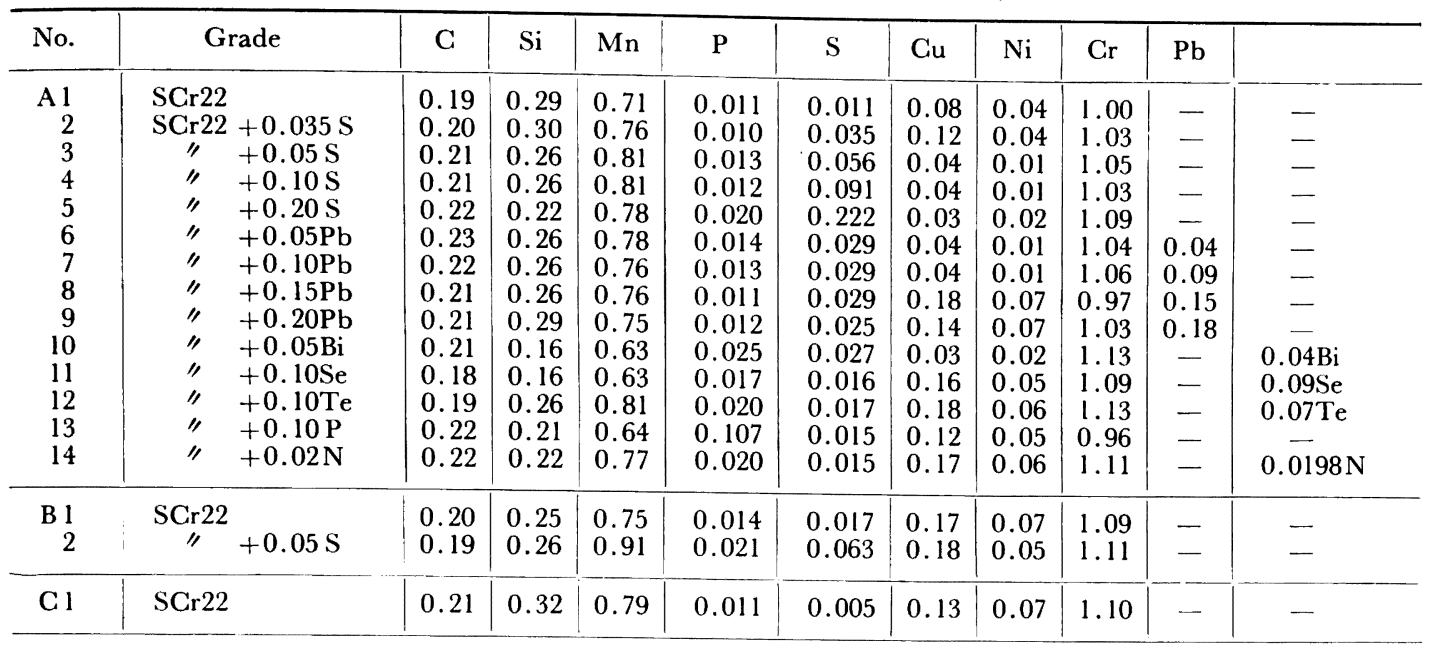

B 采列の試料は JIS, SCr22（その S 量は $0.017 \%$ ) お よびその化学組成に $\mathrm{S}$ を $0.05 \%$ 目標に添加した鋼，C 系列の試料は JIS, SCr22(そのS 量は $0.005 \%$ ) である.

$\mathrm{A}$ 系列試料のうち， $\mathrm{SCr} 22$ および $\mathrm{S}, \mathrm{Pb}$ を添加した 試料 Al〜A9 は $300 \mathrm{~kg}$ 高周波溶解炉で $300 \mathrm{~kg}$ 鋼塊 : $\mathrm{Bi}, \mathrm{Se}, \mathrm{Te}, \mathrm{P}$ およびNを添加した試料 A10〜Al4 は $20 \mathrm{~kg}$ 高周波溶解炉で $20 \mathrm{~kg}$ 鋼塊にまたた $\mathrm{C}$ 䒺列の試料は現場作業的に塩基性電炉で $2.6 \mathrm{t}$ 鋼塊に 熔製した. $300 \mathrm{~kg}$ 铜塊およびB系列の $2.6 \mathrm{t}$ 銅塊は 60 $\mathrm{mm} \phi$ :，C系列の $2.6 \mathrm{t}$ 鋼塊は $26 \mathrm{~mm} \phi$ に圧延し， また $20 \mathrm{~kg}$ 鋼塊は $40 \mathrm{~mm} \phi$ に龯伸し,切りくず処理性 試験に供した。

\section{3. 実 験 結 果}

\section{1 切りくず処理性に及ぼす快削性元素の影響}

切りくず処理性を定量的に評価する試みとしては,

H. SCHALLBROCH 54)の容積倸数および湊ら5) の切りく ず形状係数がある. 容積係数は切りくずになる前の容䅡 に対する排出された切りくずの容皘の比であり，この比 が小さい核ど切りくず処理性は良好と判定される。をた 切りくずの形状係数は吸應機を用いて，一定量の切りく ずを吸引処理する時間の長短を切りくず処理性の評侣々 している.

B. C. TEN HORN 56) は切り込みに対する送りの比 $(f / d)$ が大きくなると切りくずは折断されるとし, 切 りくずが折断される $f / d$ の限界值の大小で切りくず処 理性を評価している. $f / d$ が大きくなると, 切りくず は一般に横向きカールがはげしくなつて折断され7, こ の点に打いて $f / d$ は評価基準としての意味を有してい

\section{ると考えられる.}

これらの文献を参考にして, 本研究においてはA系列 の試料を用いて切りくず処理性に及ぼす快削性元素の影 響について倹討した. 各試料は焼準処理 $\left(920^{\circ} \mathrm{C} に 1 \mathrm{hr}\right.$ オーステナイト化後空冷) を施した後, 高速試験旋盤を 使用して, 構成刃先の影響のない切削速度 $160 \mathrm{~m} / \mathrm{min}$ で，切込みおよび送りを変えて三次元長手方向に乾式で 旋削し，切りくずの形状を観察した. そして切りくず処 理性が良好となる限界の切込みに対する送りの比 $f / d$ を求めた. 使用工具はスローアウェイタイプの超硬工具 P 20種で, 工具の刃先形状は $(-5,-5,5,5,15,15,0.8)$ である. 切りくずの形状は Fig. 1 に示すごとく, B.C. TEN HORN 56)の分類に準じて切りくずの長さおよびカ 一ル方向により分類した。すなわち, 工具や被削材など にからまりやすい連続した切りくずをA型とし，カール する切りくずについてはその軸方向の長さ $(l)$ にり, B 型 $(l \geq 50 \mathrm{~mm}), \mathrm{C}$ 型 $(l<50 \mathrm{~mm}$ 数巻き程度のカール した切りくず）およびD型（1 巻き以下のカールした切 りくず）に分類した．さらにB〜D型の切りくずはカー ル方向により， I 型（横向きまたは斜向きカールの切り くず）および型（上向きカールの切りくず）に分けた。

\begin{tabular}{|c|c|c|c|c|}
\hline \multirow{2}{*}{$\mathrm{Curl}_{\text {Cirection }}^{\text {Lenoth of }}$ ochip } & A-type & B-type & C-type & D-type \\
\hline & $\begin{array}{l}\text { Stroight or } \\
\text { tongled }\end{array}$ & $l \geq 50 \mathrm{~mm}$ & $l<50 \mathrm{~mm}$ & s। curl \\
\hline $\begin{array}{l}\text { [I type] } \\
\text { Side-or conicol- } \\
\text { curl }\end{array}$ & & $\stackrel{2001909)}{\longrightarrow}$ & $\underbrace{}_{i \rightarrow 1}$ & \\
\hline Mork & & morrs & $r \gamma$ & 2 \\
\hline $\begin{array}{l}\text { [II-type }] \\
\text { Up-curl }\end{array}$ & & 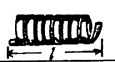 & SAg & 8 \\
\hline Mork & & 7rrorr & 878 & 2. \\
\hline
\end{tabular}

Fig. 1. Classification of chip forms. 


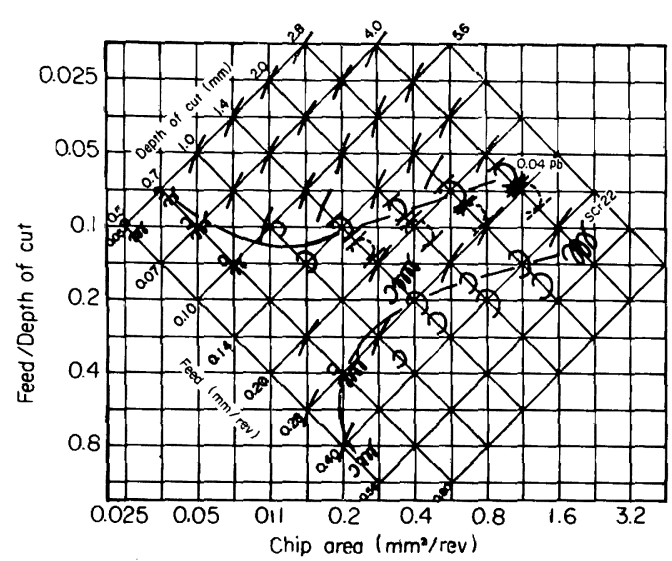

Fig. 2. Critical chip breaking feeds for steel Al (SCr22) and A6 (SCr22+0.04\% Pb).

そして $l<50 \mathrm{~mm}$ の切りくず (C型およびD型)を切り くず処理性が良好と判定し，切りくず処理性良否の基準 とした。

焼準処理を施した試料の顕微鏡組織はい多れもフェラ イトー層状パーライト組織でその硬度は $\mathrm{H}_{\mathrm{B}} 149$ １70で ある.

Fig. 2 KCr22 およびその化学組成に Pbを0.04\% 添加した試料 A6 の切りくず形状を切り込みおよび送り との関倸において示した.なお切りくずの形状はFig. 1 に示す記号で図示してある. Fig. 2 より知られるよう に， $f / d$ が大きくなると切りくずはカールし折断され るが，切りくず処理性が良好と判定される $f / d$ の限界 值を結んで得られる曲線は $\mathrm{Pb}$ 䘮 $0.04 \%$ 添加すること により $f / d$ の小さい方に移行し， $\mathrm{Pb}$ による切りくず

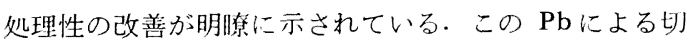
りくず処理性の改善は, 切削面賸の小さい, 寸なわち仕 上切削において顕著である. なお Fig. 2 において, $\mathrm{SCr} 22$ の切りくず処理性が良好となる $f / d$ が切込みの 小さい場合大きくなるのは，ノーズ半径のため $f: d$ と (切削厚さ/切削幅) が比例せず，切削断面が扁平になる ことによるカール傾向の低下゙によるものと考えられる・

切りくずカール方向についてみると, SCr22では斜向 きカール(I 型)であるのに対し， $\mathrm{Pb}$ が $0.04 \%$ 添加さ れた試料 A6 では切込みの大きい場合上向きカールの切 りくず（II 型）が生成される．上向きカールを有する切り くずの生成は，Sを $0.09 \%$ 以上添加した試料 A4 およ び A5, Pbを添加した試料 A6〜A9, および Bi を添 加した試料 A 10 において観察されたが， Se，Te，Pお よびNを添加した試料ではいずれも斜向きのカールの切 りくず (I 型)が生成された。このような快削性元素添加

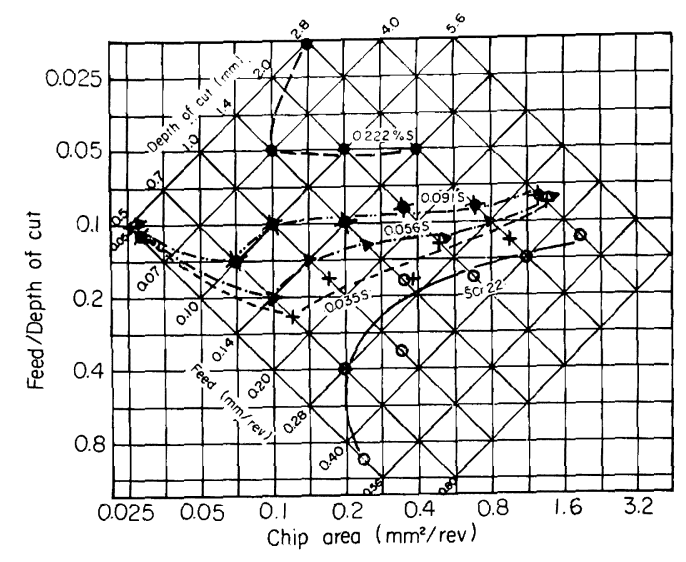

Fig. 3. Effect of sulfur on the breaking feeds for SCr22.

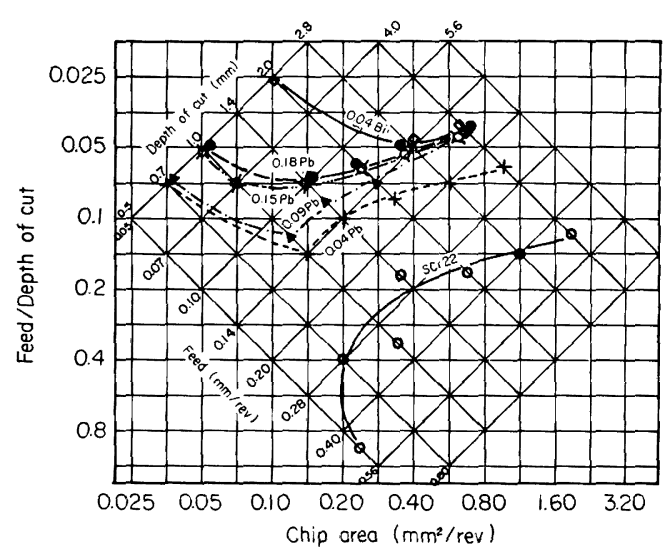

Fig. 4. Effects of lead and bismuth on the critical chip breaking feeds for SCr 22 .

による上向きカールを有する切りくずの生成は，快削性 元素により切りくずの横ひろがりが小さくなり横方向へ の切りくずのカール傾向 ${ }^{7)}$ が滅じることおよび工具と切 りくずの接触面栍の減少にもとづく上向き方向へのカー ル傾向 ${ }^{8)}$ の增加によるものであろう.

A系列の他の試料についても，Fig. 2 と同じように， 切りくず処理性が良好となる $f / d$ の限界曲線を求め,

Fig. 3 にS 添加の影響を, Fig. 4 に $\mathrm{Pb}$ および $\mathrm{Bi}$ 添加

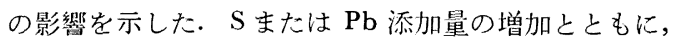
切りくずのカールする範囲はより小さい $f / d$ まで広が り，切りくず処理性が改善される．Bi は $0.04 \%$ 程度 の少量添加で切りくず処理性を改善する効果が影著であ る.また $\mathrm{S}$ および $\mathrm{Pb}$ の切りくず処理性に及ぼす効果を 比較すると, 特に軽切削領域において $\mathrm{Pb}$ の添加がより 効果的である. 


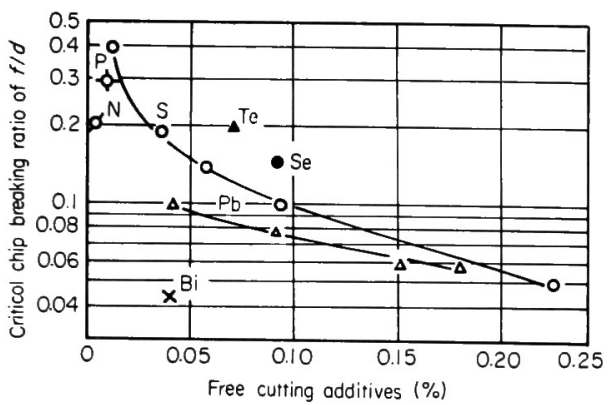

Fig. 5. Relation between the critical chip breaking ratio of $f / d$ and the amounts of free-cutting additives.

快削性元素が切りくず処理性に及ぼす効果を比較する ため，切削面積が $0.2 \mathrm{~mm}^{2} / \mathrm{rev}$ 亿おける切りくず処理 性が良好となる $f / d$ の限界值を， $\mathrm{S} ， \mathrm{~Pb}$ および $\mathrm{Bi}$ に ついて Fig. 3 および Fig. 4 より， Se，Te，P およ

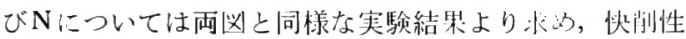
元素量との関係において Fig. 5 に示した. 同一重量\% の快削性元素の添加で比較する上，切りくず処理临が良 好となる $f / d$ の限界值は， $\mathrm{Bi}<\mathrm{Pb}<\mathrm{S}<\mathrm{Se}$ および $\mathrm{Te}$ の順である.す交わち同一重留\%の快削性元素の添加に よつて得られる切りくず処理性の改善効榡は, $\mathrm{Bi} \times \mathrm{Pb}$ $\mathrm{S}>\mathrm{Se}$ および Te の順になる. N および $\mathrm{P} の$ 切りくず処 理性を改善する効果は比較的小さい。

現場作業的にはSを $0.04 〜 0.07 \%$ 添加した硫黄快削 鋼の切りくず処理性は， $\mathrm{Pb}$ を $0.10 \sim 0.20 \%$ 添加した 鉛快削鋼に比較して劣つていると同時に，そのばらつき の大きいことが経験されている. Fig. 5 より知られるご とく，鉛快削鋼に相当する切りくず処理性を得るために は約 $0.15 \%$ 以上の S 添加が必要と考光られる. 末た $0.04 \sim 0.07 \%$ S が添加された硫黄快削鋼の切りくず処 理性のばらつきが大きいのは，Fig. 5 において， $\mathrm{S}$ 量の 規格内 $(0.04 \sim 0.07 \%)$ のばらつきにもとづく $f / d$ の限 界值の変動が大きいことに原因すると考えられる。

\section{2 切りくず処理性に及ぼす熱処理組織の影響}

一般に，肌焼鋼はフェライトー層状パーライト組織に 焼準または焼鈍処理され切削されるか，または球状化焼 鈍後冷間鍛造され，しかる後に仕上加工に供せられる。 そこで本実䮖でも，B系列の試料，すなわち SCr22 お よびその化学組成に Sを $0.063 \%$ 添加した試料学用い, 焼準，焼鈍および球状化焼鈍を施し，切りくず処理性に およぽす熱処理組織の影響について検討した。なお焼準 処理は $920^{\circ} \mathrm{C}$ に $1 \mathrm{hr}$ オーステナイト化後空冷, 焼鈍 処理は $920^{\circ} \mathrm{C} に 1 \mathrm{hr}$ オーステナイト化後炉冷, 球状

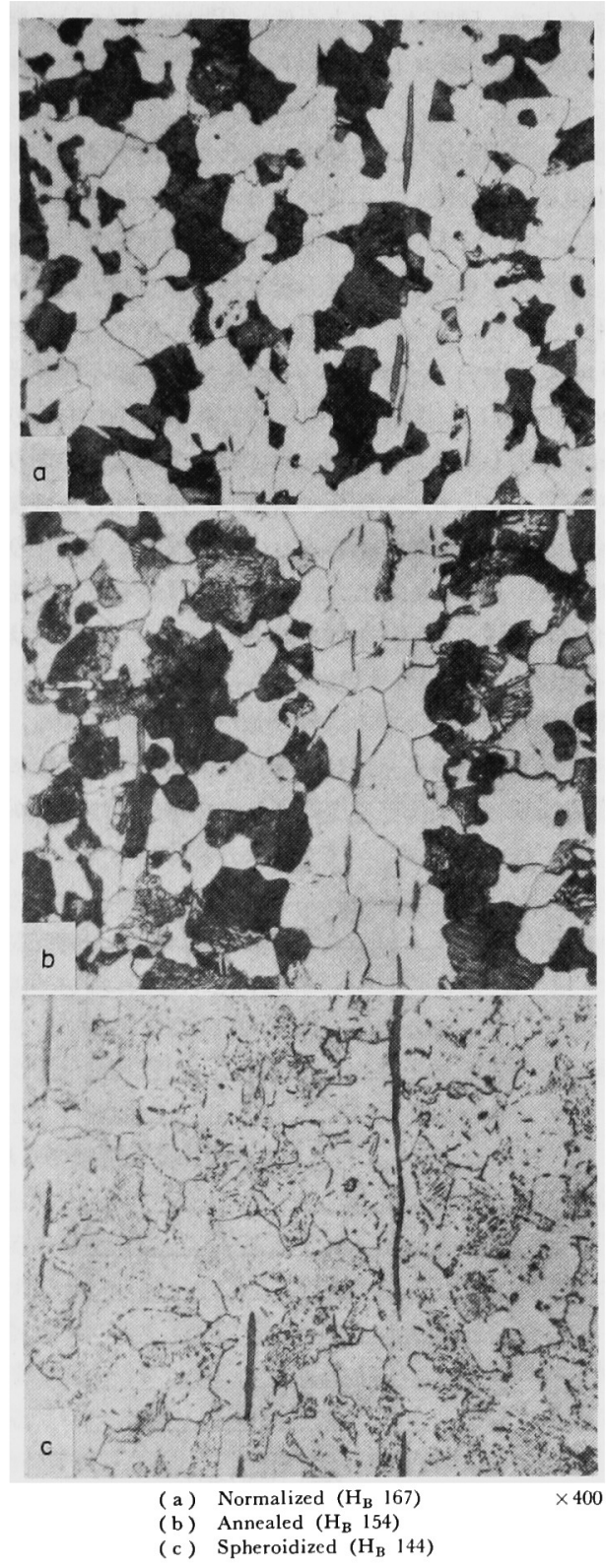

Photo. 1. Microstructures of steel B2 $(\mathrm{SCr} 22+0.063 \% \mathrm{~S})$.

化焼鈍処理は $750^{\circ} \mathrm{C}$ に $5 \mathrm{hr}$ 保持後 $600^{\circ} \mathrm{C}$ まで $20^{\circ}$ C / hr の泠却速度で徐冷することにより施した。

試料 B 2 の熱処理組織掞よび硬度を Photo. 1 に示し た. 㷪準および焼鈍組織はいずれもフェライトー層状ハ ーライトであるが，㮱鈍組織は縞状を呈し，焼準組織よ りも硬度は低い(Photo. 1 ( a ) および (b)). 球状化焼鈍 組織は主にパーライトコロニー内で球状化が進行したバ 
ーライトで, 硬度はもつとも低い(Photo. 1 (c)). 試料 B1の熱処理組織および硬度は試料 B2 のそれらと间程 度である。

熱処理組織が切りくず処理性に及ぼす影響は，快削性 元素のそれに比較して小さいことが手想されるため，本 実験では切りくず処理性の微妙な差まで判定できるよう に，切りくずを形状別にその重量比であらわす方法:日 を 採用した。李わ方，切削速度 $120 \mathrm{~m} / \mathrm{min}$ ，切り込夾 $1.6 \mathrm{~mm}$ において，送りを $0.1 \sim 0.4 \mathrm{~mm} / \mathrm{rev}$ に変えて $8 \mathrm{sec}$ 間旋削し，採取した切りくずを Fig. 1 の切りく ず分類表にしたがつて分類した. そして形状別の切りく ずの重量比を送りとの関係で整理し, 処理性の良好な切 りくずが生成されはじめる送りの大小でもつて，切りく ず処理性の良否を判定した．なお工具はスローアウェイ タイプの超硬工具 P 10 種を使用し, その刃先形状は $(-5,-5,5,5,15,15,0.8)$ である.

熱処理組織を異にする試料 $\mathrm{Bl}$ (SCr22) に打ける，切 りくずの形状別の重量比と送りとの関倸を Fig. 6 に示 した. 小さい送りではA型の切りくずが生成されるが,
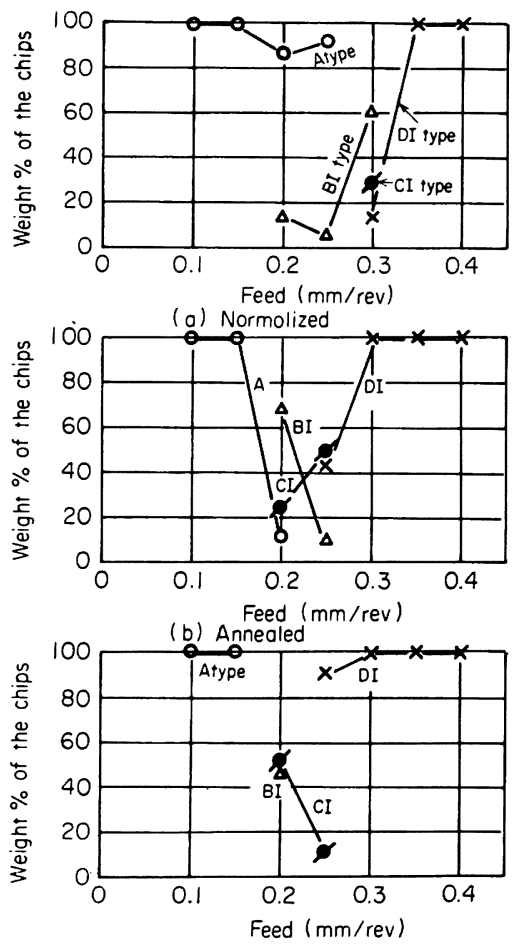

(c) Spheroidized

Fig. 6. Relation between the weight percent of the type of chips and the feed for steel B1 (SCr22).
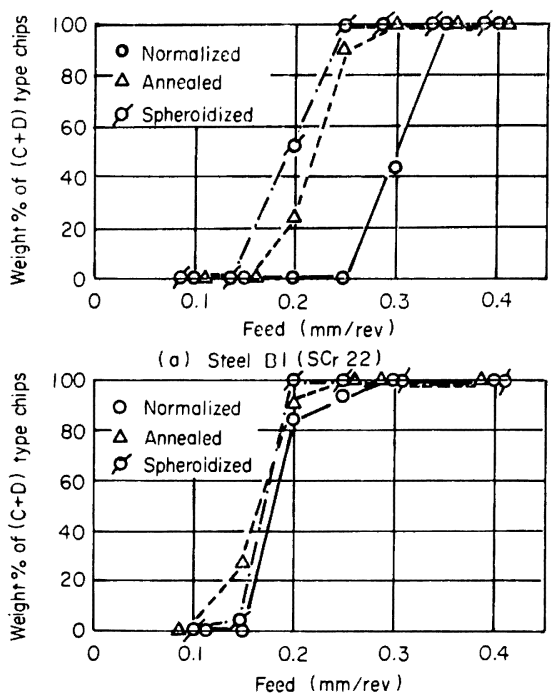

(b) Steel B2. ( $\mathrm{SCr} 22+0053 \% \mathrm{~S})$

Fig. 7. Relation between the weight per cent of $(\mathrm{C}+\mathrm{D})$ type chips and the feed for steels $\mathrm{Bl}$ and $\mathrm{B} 2$.

送りの増加とともに切りくずは B 型および $\mathrm{C}$ 型に移行 し，さらに送りが大きくなると $\mathrm{D}$ 型の切りくずのみにな る. そして中間の送りでは形状の異なる切りくずが混在 している. 送りの増加にともなうこのような切りくず形 状の変化は試料 B 2 においても同じであつた。

試料 B 2 についても Fig. 6 と同様な実験を行ない， 切りくず処理性が良好な $(\mathrm{C}+\mathrm{D})$ 型切りくずの重量比を 送りとの関係で整理すると Fig. 7 のごとく示される. $(\mathrm{C}+\mathrm{D})$ 型切りくずに移行する送りは, 試料 B 1 では球 状化焼鈍組織がもつとも小さく，ついで焼鈍，焼準の順 である. (Fig. 7 (a)).すすなわち, 切りくず処理性は球 状化焼鈍組織がもつとも寸ぐれ，ついで焼鈍組織，焼準 組織の順である. 一方 S が $0.063 \%$ 添加された試料 B 2 の切りくず処理性は熱処理組織により汪とんど影響を受 けない(Fig. 7 (b))。 このことは試料 B 2 では熱処理組 織の差によつて切りくず処理性にほとんどばらつきを生 じないという現場作業的に有利な特長を有しているとい える.

試料 B 1 と試料 B 2 の切りくず処理性を比較して知ら れるごとく，いずれの熱处理組織においても切りくず処 理性は試料 B 2 の方がすぐれているが, 特に焼準組織に 打いて切りくず処理性を改善する $\mathrm{S}$ の効果が大きくあら われている。 


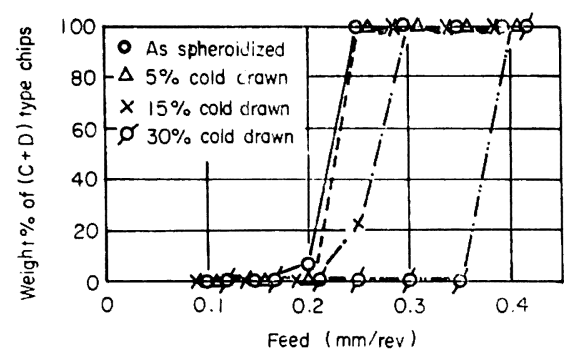

Fig. 8. Relation between the weight per cent of $(C+D)$ type chips and the feed for cold drawn steel Cil (SCr22).

\section{3 切りくず処理性に及ぼす冷間加工の影響}

肌焼銅が冷間鍛造される場命，冷銭性を考虑し前処理 として球状化焼鈍されることが多い，本実䮖においても 球状化焼鈍組織の切りくず処理性に及ぼす冷間加工の影 響について検討した。

試料は SCr22（試料 C1）を使用し，球状化焼鈍を施 した徯，冷間加工として断面減少率で 5,15 および 30 \%の冷間引抜を行ない，切りくず処理性試験に供した. 球状化焼鈍方法は前述したB系列のそれと同一で，その 熱処理組織は試料 B 2 における球状化焼鈍組織 (Photo. 1 (c)) と同程度である.なお球状化焼鈍のまま，5，15 および 30\% の泠間引抜を行なつた試料の硬度はそれぞ れ $\mathrm{H}_{\mathrm{B}}$ 131，162，174 および 189 である.

切りくず処理性試験の方法は熱処理組織の検討の場合 々同一である. Fig. 8 に切りくず処理性が良好な（C+ D) 型切りくずの重量比と送りとの関係を示した. 切り くず形状が C 型およびD型に移行する送りは, 球状化焼 針のま立および $5 \%$ 冷間引抜鋼においてもつとも小さ く, ついで 15\% 冷間引抜鋼，30\% 冷間引抜鋼の順にな つている. 球状化焼鈍のままと $5 \%$ 泠間引抜鋼の切りく ず形状をさらに詳細に比較すると, $0.25 \mathrm{~mm}$; $\mathrm{rev}$ の送り で両者の切りくずは $(\mathrm{C}+\mathrm{D})$ 型が 100\% であるが，こ のうちD型の切りくずの重量比は球状化焼鈍のままの試 料で約 93\%，5\% 冷間引抜鋼では約 50\%であり，また カール径のばらつきは $5 \%$ 冷間引抜鋼においてより大き く，切りくず処理性が $5 \%$ の泠間引抜により不安定にな ることが知られた.

以上の実験結果を総合すると, 切りくず処理性は冷間 引抜率の増加とともに劣化すると結論される.なお本実 験において生成された切りくずのカール方向は冷開引抜 の有無によらずいずれも斜向きであつた.

\section{4. 考察}

切りくず処理性は主として切りくずの幾何学的形状お
よび切りくずの破断歪によつて解釈される. 切りくずが 折断されるためには,切りくずがカールし，かつ被削材， 工貝逃げ面などの障害物にあたつて切りくずの自由な進 行が彷げられ，切りくずの粗面が引張り側になるような 曲げモーメントを受け，曲げモーメントが最大の位置で 折断される場合が多い10). そして切りくずが折断するか どうかは，切りくずの最初の半径 $R_{\mathrm{O}}$ と工具の下を通り 抜けて離脱し得るための半径 $R_{\mathrm{L}}$ との差によつて $t_{2}$ の

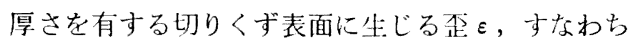

$$
\varepsilon=t_{2} / 2\left(1 / R_{\mathrm{O}}-1 / R_{\mathrm{L}}\right)
$$

がその切りくずの破断歪をこえるかどうかによつて決定 される1). したがつて切りくずのカール半径が小さく， その厚さが大きく, 切りくずの破断歪が小さいほど切り くずは折断されやすい.

上述したように，切りくずの折断にとつて切りくずの カールは必要条件である. 切りくずのカールは切削㙨 構，切削抵抗および切削温度に関連した現象であり， 種々の機構7)8)11) 13)が提案されているが，切りくずの力 一ルと被削材の治金学的要因および切削条件との関係に ついては充分解明されていないのが現状である。

さらに切りくずの破断歪については，切りくずがその 生成過程において著しく变形を受け，加工硬化と同時に 動的回復が進行しつつあること，高歪の部分ではミク口 クラックの発生が認められる場合のあること，および切 りくずが折断されるときの平均的な温度は青熱脆性域に 達しているなどの特徽をも考虑する必要がある.

\section{1 快削性元素の影響について}

臼井 $\left.{ }^{8}\right)$ は快削性元素 $(\mathrm{S}, \mathrm{Pb})$ により切りくずが分断さ れるのは，工具と切りくずの接触面積が小さくなり切り くずのカール径が小さくなることおよび快削性元素によ る脆性が切りくずを脆くするためであるとしている.

また荒不 ${ }^{14)}$ は，快削性元素の切りくずの破断昰に及ぼ 寸効果について，MnS で代表される非金属介在物は鋼 中の不均質を增し，高歪部分の鋼の内部切欠きによりる ク口龟裂の発生一連結をうながし，切りくず中にせん断 的破断面を導入するのに対し，Pb で代表される金属介在 物は $250^{\circ} \mathrm{C} \sim 500^{\circ} \mathrm{C}$ の範用で $\mathrm{Pb}$ が液化上ともにミク 口亀裂の内面に浸透して黾裂の伝播エネルギーを下げ， 破断歪を著しく低下せしめると考察している.

切りくず処理性を改善する快削性元素の効果は, Fig. 5 に示されるように, 同一重量\%のそれらの添加で比較 すると $\mathrm{Bi}>\mathrm{Pb}>\mathrm{S}>\mathrm{Se}$ および Te の順になつている. $\mathrm{S}, \mathrm{Se} お よ ひ ゙ \mathrm{Te}$ はその切りくず処理性を改善する機橪 が類似したものとして考えられるため，同一原子\%でこ れら快削性元素の効果を比較すれば同じ程度に評俩でき 


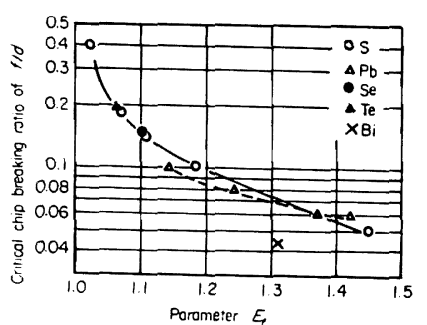

$E_{t}=\left[1+64\left(\% \mathrm{~S} / 32+\% \mathrm{Se} / \mathrm{T}_{9}+\% \mathrm{~T}_{\mathrm{e} / 127}\right)\right] \times\left[1+2(\% \mathrm{~Pb})+6\left(\% \mathrm{~B}_{1}\right)\right]$

Fig. 9. Relation between the critical chip breaking ratio of $f / d$ and the parameter $E_{f}$.

るのではないかと思われる．また $\mathrm{Pb}$ 抽よ゙ $\mathrm{Bi}$ の効果 については， $\mathrm{Pb}$ および $\mathrm{Bi}$ を添加した試料 $\mathrm{A} 6$ 〜 $\mathrm{A} 10$ では，Se，Te，P および N を添加した試料に比較して $\mathrm{S}$ 量の水準が高く $(0.025 \sim 0.029 \% \mathrm{~S}), \mathrm{Pb}$ または $\mathrm{Bi} の$ 効果のほかに $\mathrm{S}$ による相乘効果が加算され，切りくず処 理性に及ぼす $\mathrm{Pb}$ または $\mathrm{Bi}$ の効果が過大評価されてい るのではないかと愳念される.

そこで非金属快削性元素 (S, Se, Te）拈よび金属快削 性元素 $(\mathrm{Pb}, \mathrm{Bi})$ の効果が相乘的に効くこと，および $\mathrm{S}$, Se およびTeについてはその原子量を考虑した効果係数 $E_{f}{ }^{15)}$ で Fig. 5 の実験結果を整理して Fig. 9 に示した。 なお効果係数 $E_{f}$ は次式で与えられている.

$$
\begin{aligned}
& E_{f}=[1+64(\% \mathrm{~S} / 32+\% \mathrm{Se} / 79+\% \mathrm{Te} / 127)] \\
& \times[1+2(\% \mathrm{~Pb})+6(\% \mathrm{Bi})]
\end{aligned}
$$

Fig. 9 に示されるように, S, Se および Te の切り くず処理性を改善する効果は，効果係数によつて一義的

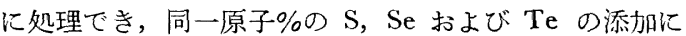
よる切りくず処理性改善効果は同じ程度に評価すること ができる.また $\mathrm{Pb}$ および $\mathrm{Bi}$ の切りくず処理性を改善 する効果は, 共存する $\mathrm{S}$ との相乘効果を差引いても， $\mathrm{S}$, $\mathrm{Se}$ および $\mathrm{Te}$ のそれよりも大きいことが明らかである. 金属快削性元素 $(\mathrm{Pb}, \mathrm{Bi})$ の切りくず処理性を改善す る効果が非金属快削性元素 $(\mathrm{S}, \mathrm{Se}, \mathrm{Te})$ のそれに比較して 大きい理由は, $f / d$ が小さくても前者の切りくずをカー ルさせる傾向が大きいことおよび青熱脆性域における著 しい脆化作用によるものと考えられる．Pb がSに比較 して小さい $f / d$ においても切りくずをカールさせる効 果が大きいのは， $\mathrm{S}$ および $\mathrm{Pb}$ の被削性を改善する機構 の相湋によるもの上思われる。すなわち， $\mathrm{Pb}$ の被削性 改善機構が主として切りくずと工具の接触域における鋼 中 $\mathrm{Pb}$ の直接潤滑作用であるのに対して，Sのそれは主 として切りくずせん断域における MnS の応力集中源と しての作用にもとづいている16). したがつて $f / d$ が小
さい場合（切りくずの体積に対する表面積の比が大き い), $\mathrm{Pb}$ の効果は $\mathrm{S}$ より もきく ${ }^{16)}$, 工具刃先の切りく ず接触面積の減少にもとずく切りくずのカール傾向も $\mathrm{Pb}$ 添加においてより大であると考えられる。

つぎに切りくずの破断歪に及ぼす金属快削性元素と非 金属快削性元素の効果を比較すると，前述した荒不 ${ }^{14) の ~}$ 指摘のように，青熱脆性域の延性の低下は， $\mathrm{S}$ 添加の場 合に比較して，Bi および $\mathrm{Pb}$ 添加の場合にはその融解 およびぬれ現象により著しく助長され, 特に Bi 添加の 場合その作用が大である17)。この Bi および $\mathrm{Pb}$ おる 青熱脆性域における著しい延性の低下は，これら元素の 添加によつて小さい送りでカールした切りくずの折断に 効果的にはたらいているものと考察される.なんとなれ ば，送りが小さく，さらに快削性元素の添加により切り くずがうすく，したがつて切りくずの表面に生じる昰 $\varepsilon$ が小さい場合の切りくずの折断にとつて, 切りくず折断 時の切りくずの平均的温度と推定される青熱脆性温度域 での延性の著しい低下は重要であるからである.

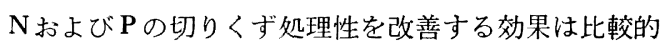
小さい. $\mathrm{N}$ おび $\mathrm{P}$ はフェライ中に固溶して延性を下 げ，工具刃先の切りくず接触面積を減じることにより， 切りくずのカール傾向を助長するが，切りくずの破断歪 を低下せしめる効果は, 被削材が切りくずの生成過程に おいて著しく加工硬化されることを考虑すると, 両元素 の添加による被削材の延性の低下から予想されるほど大 きくないと考えられる.

\section{2 熱処理組織および冷間加工の影蟑について}

Cr 肌熱鋼の切りくず処理性は, 球状化焼鈍組織がもつ ともすぐれ，ついで焼鈍組織，焼準組織の順である。し かし Sが $0.063 \%$ 添加された $\mathrm{Cr}$ 肌焼鋼では, 熱処理組 織により，切りくず処理性はほとんど影響を受けない。 また球状化焼鈍組織を有する Cr 肌焼鋼の切りくず処理 性は，冷間引抜率の增加とともに劣化する。

切りくずのカールは上向き方向と横向き方向との成分 に分解して考えることができる. 上向きカールは，切り くずのカールの幾何学的棈成から, 工具と切りくずの接 触面積に支配される ${ }^{8)}$ ．横向きのカールは，切りくずの 横ひろがりに関連している，すなわち，切りくずが生成 される場合, 切削幅の自由面に近い部分では，横ひろが りをおこしこの部分が内側になるようにカールする7). したがつて，一般には延性の小さい被削材では，せん断 角が大きく, 工具と切りくずの接触面積が小さくなり， 上向きカール傾向が大きく，一方延性の大きい被削材で は切りくずの横ひろがりが大きく，横方向へのカール傾 向が大きくなると考えられる. 
熱処理組織を異にする試料 B 1 および試料 B 2 の切り くずの厚さ, 幅と送りとの関係を Fig. 10 に，切りくず のカール直径と送りとの関係を Fig. 11 に示した. 切り くずの厚さおよび幅は， $\mathrm{S}$ 添加により小さくなるが，熱 処理組織との関係についてみれば，それらは球状化烍鈍 組織>焼鈍組織>焼準組織の順である(Fig. 10).つぎに カール直径は, 試料 B 1 では, 球状化焼鈍組織<焼鈍組 織く焼準組織の順であるが，試料 B 2 では，焼準組織く

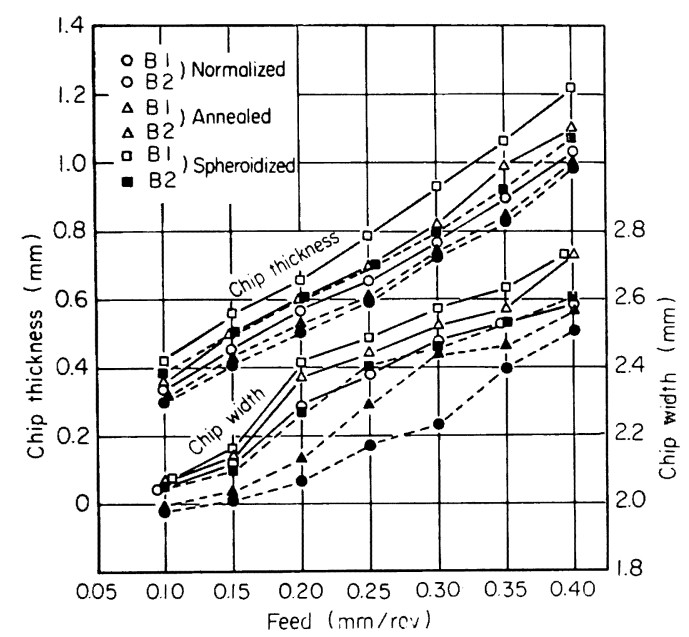

Fig. 10. Relation between the thickness and the width of chips and the feed for B-series steels with different heat-treated structures.

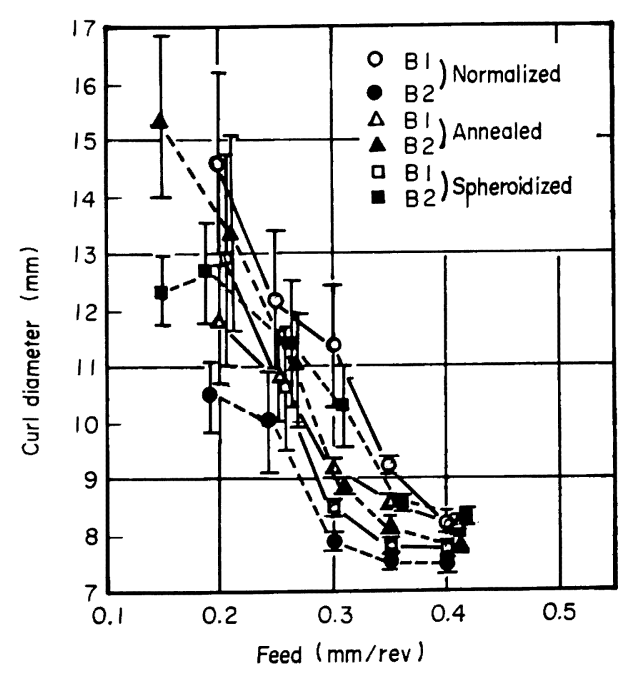

Fig. 11. Relation between the curl diameter of a chip and the feed for $B$ series steels with different heat-treated structures.
焼鈍組織 <球状化㹸鈍組織の順で, 試料 B 1 と試料 B 2 のカール直径と熱処理組織との関係は逆になつている.

冷間引抜沵を異にする球状化焼鈍組織の試料Ｃ１の切 りくずの厚さ，幅と送りとの関係を Fig. 12 に，その力 一ル直径と送りとの関係を Fig. 13 に示す. 冷間引抜率 の増加とともに, 切りくずは薄く, その幅は小さく, 力 一ル直径は大きくなる.

Fig. 10〜Fig. 13 の結果より, 切りくずのカール直径 を切りくずの幅との関係において整理すると Fig. 14 の ごとく示される. 熱処理組織を異にする試料 B 1 の切り くずのカール直径とその幅との関係は，あるばらつきを 有する曲線で示され, 切りくずの幅の増加とともにカー

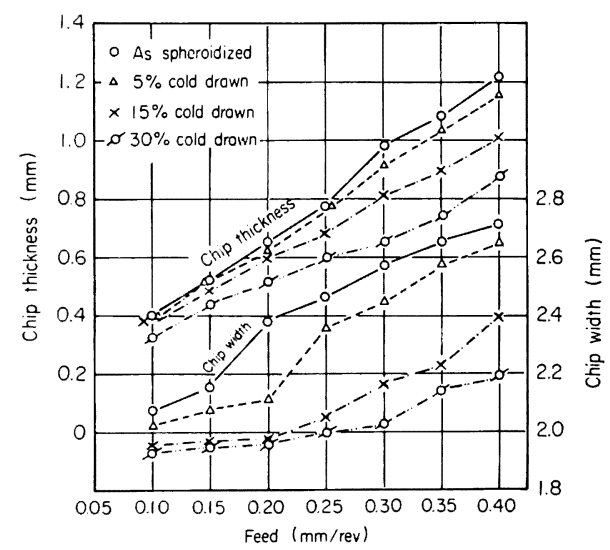

Fig. 12. Relation between the thickness and the width of chips and the feed for cold drawn steel C1 (SCr22).

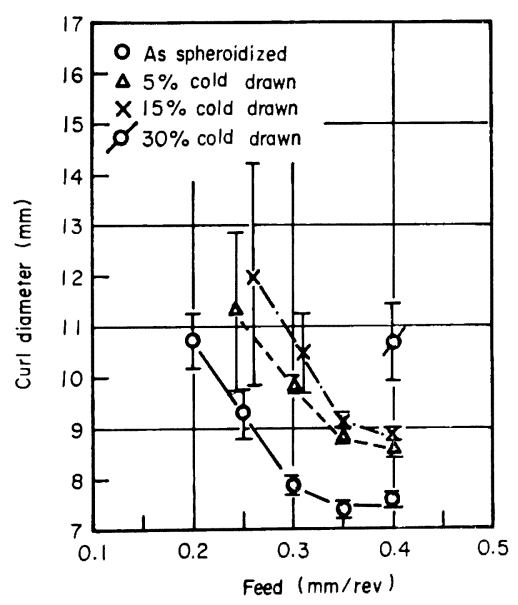

Fig. 13. Relation between the curl diameter of a chip and the feed for cold drawn steel C1 (SCr 22). 


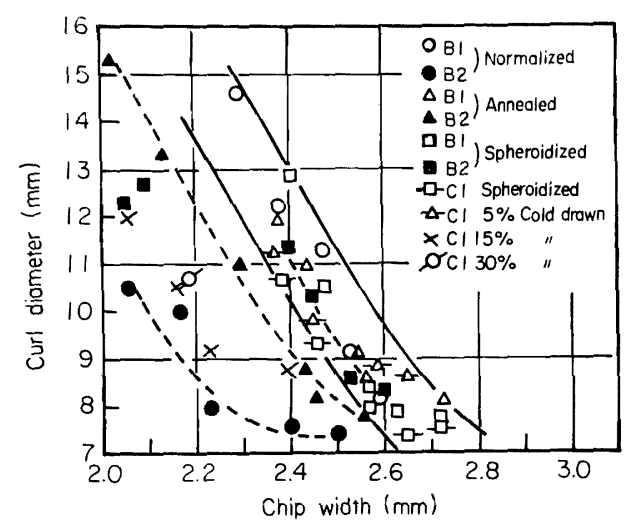

Fig. 14. Relation between the curl cliameter and the chip width.

ル径は減少することが知られる、このことより,試料 B1 の切りくずのカール方向が斜向きであることをあわせ考 虑すれば，カール径が主として切りくずの横ひろがりに よつて律せられているものと考えられる。したがつて試 料 B1の切りくずのカール径が, 球状化焼鈍組織<烓鈍 組織く烍準組織の順であるのは (Fig. 11)，切りくずの

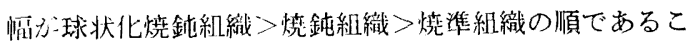
と(Fig. 10) より説明忘れる. しかし，Fig. 14 より知ら れるごとく，焼準および焼鈍組織の試料 B 2，15\%およ び 30\% の泠問引报率を有する試料 C 1 の切りくずの力 一几径は, 同一水準の切りくずの幅を有する試料 B 1 の それよりも小さい：これらの試料では，切りくずの横ひ ろがりによる橫方向へのカール機構のほかに, 切りくず が薄いことより (Fig. 10 および Fig. 12), 工具と切りく ずの接触面積の小さいことが予想され，このため上向き カールが助長され, その効果が加算された結果と考えら れる.したがつて, 冷間引抜率の增加とともに, 切りく ずのカール径が大きくなるのは(Fig. 13), 泠間引抜率の 增加とともに切りくずの横ひろがりが大きく抑制され (Fig. 12), 横方向へのカール傾向が減じる一方, 同時に 工具と切りくずの接触面積の減少により上向きカールの 傾向は増大するが，前者の効果が大きいためであろう. また Sが 0.063\% 添加された試料 B 2 では, 切りくず のカール径は焼準組織<焼鈍組織 $<$ 球状化焼鈍組織の順 であるが(Fig. 11)，これは S 涯加により切りくずの横ひ ろがりが抑制された結果 (Fig. 10)，横向きカール傾向よ りも工具と切りくずの接触面積の大小にもとづく上向き カール傾向の熱処理組織による差が大きくあらわれたも のと考光られる.

いずれにしても切りくずのカール機構は切りくず処理

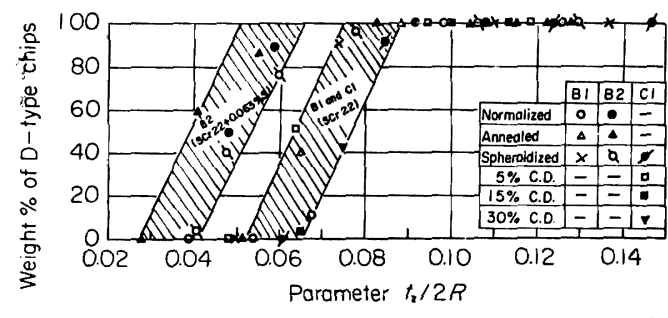

Fig. 15. Relation between the weight per cent of D-type chips and the parameter $t_{2} / 2 R$.

性にとつてもつとも重要な要素であり, カール機構と被 削材の治金学的要因との関係の詳細な検討は今後に残さ れた大きい課題であると思われる.

さて切りくず表面に生じる亜が（1）式に示されるごと く, 切りくずのカール直径 $(2 R)$ と厚さ $\left(t_{2}\right)$ に影響さ れることを考虑し，切りくずのカール直径に対する厚さ の比 $\left(t_{2} / 2 R\right)$ をパラメーターこして, 試料 $\mathrm{B} 1$ につい ては Fig. 6 より, 試料 B 2 および $\mathrm{C} 1$ とついては同図 と同様な実駼結果より，D型切りくずの占める重量比を 整理すると Fig. 15 のごとく示される.

切りくずの形状がD型に移行するパラメーター $\left(t_{2} /\right.$ $2 R)$ の值は, $\mathrm{SCr} 22$ (試料 $\mathrm{A} 1, \mathrm{~A} 2$ ) と試料 $\mathrm{B} 2$ ( $\mathrm{SCr} 22$ $+0.063 \% \mathrm{~S})$ においてあるばらつきの幅を有する 2 本 の直線で区別され， $\mathrm{D}$ 型切りくずに移行する $t_{2} / 2 R$ の值 は後者の方が小さい．またこのD型切りくずに移行する $t_{2} / 2 R$ の值は熱処理組織および泠間加工によらずばらつ きの範囲内で一定である.このことより切りくずの破断 歪は $\mathrm{S}$ 涯加によつて低下寸るが，熱処理組織および冷間 加工によりほとんど変化しないことが知られ，切りくず 処理性におよぼす熱処理組織および冷間加工の影響が主 として切りくずの幾何学的形状によつて解釈できること になる.つまり試料 B 1 の切りくず処理性がそのすぐれ ている順に球状化烧組鈍織>焼鈍組織>焼準組織である のは，上記した順に切りくずが厚くかつそのカール直径 が小さいためであり, 試料 B 2 の切りくず処理性が熱処 理組織によつてほとんど影響を受けないのは, 切りくず の厚さおよびカール直径が球状化焼鈍組織>焼鈍組織> 炾準組織の順に大きく, 切りくずの歪 $\varepsilon$ への寄与が相殺 されるためである. \&た冷間引抜率の増加とともに切り くず処理性が劣化するのは，切りくずがうすくかつその カール直径が大きくなるためである.

被削材の破断昰は熱処理組織および椧間加工によつて 大きな影響を受ける.球状化焼鈍組織の破断企は焼準組 織よりも大きく18), 冷間加工率の增加とともに被削材の 破断程は著しく低下する ${ }^{19}$. 被削材は切りくずの生成過 
程において大きな変形を受け著しく加工硬化されるが, 被削材の延性が小さい泣どその変形量および加工硬化の 程度は小さい.さらに炭化物の分布も大きい変形のため せん維状になる．結局熱処理組織の相違および泠間加工 の有無にもとづく切りくずの破断歪の差は，被削材のそ れの差に比較して，よほど小さくなつているものと考元 られる。

以上 $\mathrm{Cr}$ 肌焼鋼について，切りくず処理性におよぼす 快削性元素，熱処理組織および冷間加工の影響に関する 検討を行なつてきたが，快削性元素の種類およびその添 加量によつて, その改善効果が相違すること, 切りくず 処理性が熱処理組織によつて大きな影暗を受けることお よび冷間加工によつて劣化することを明らかにした。こ れらの結果より切りくず処理性の安定化という立場から は，適切な熱処理組織の選択および冷間加工の影響を， さらに切りくず処理性の改善および安定化をはかるため には快削性元素の選択およびその添加量をも, 現場作業 的見地から十分考慮されねばならないと結諭される。

\section{5. 結言}

Cr 肌焼鋼の切りくず処理性におよぼす快削性元素, 熱 処理組織および冷間加工の影響について検討した結果， 次の諸結果を得た。

（1）焼準処理を施した Cr 肌焼鋼の切りくず処理性 を改善する効果は, 同一重量\%の添加量で比較すると, $\mathrm{Bi}>\mathrm{Pb}>\mathrm{S}>\mathrm{Se}$ および $\mathrm{Te}$ の順である. しかし同一原子 \%のそれらの添加量で比較すると非金属快削性元素であ る $\mathrm{S}, \mathrm{Se}$ および Te の効果は同じ程度に評価できる， N および $\mathrm{P} の$ 切りくずを改善する効果は比較的小さい.

（2）金属快削性元素である $\mathrm{Bi}$ および $\mathrm{Pb}$ の切りく ず処理性を改善する効果が大きい理由としては, 非金属 快削性元素に比較して切り込みに対する送りの比 $(f / d)$ が小さい切削条件においてもカール傾向の大きいことお よび $\mathrm{Bi}, \mathrm{Pb}$ の融解, ぬれ現象による青熱脆性温度域で の著しい脆化作用があげられる.

（3） Cr 肌焼鋼の切りくず処理性は球状化焼鈍組織 がもつともすぐれており，ついで焼鈍組織，焼準組織の 順である.しかし Sが 0.063\% 添加された Cr 肌焼鋼で
は，熱処理組織によつて切りくず処理性はほとんよ゙影響 されない.

（4）球状化焼鈍組織有する Cr 肌焼鋼の切りくず 処理性は冷閒引抜率の増加とともに少化する.

（5）切りくず処理性におよぼぼす熱処理組織および 冷間加工の影響は主としてその幾何学的形状, 与なわち 切りくずのカール直径に対する切りくずの厚さの比 $\left(t_{2}\right)$ $2 R)$ により解釈される. その比が大きいと短かく折断さ れた切りくずが生成される.

（6） S 添加により，短かく折断した切りくずを生成 する限界の $t_{2} / 2 R$ 值は小さくなる. これは $\mathrm{S}$ 添加によ る切りくずの破断歪の低下によるものと考えられる.

\section{文献}

1) 中山：日本機械学会論交集，27(1961)6, p. 833

2 ) 伊藤, 高橋, 木村, 山野: 機械技術, 21 (1973), p. 24

3 ) 山本, 熊谷: 鉄と鋼, 59 (1973) 1, p. 100

4) $H$. Schallbroch, $H$. Willicks, and $H$. BathMANN: Metalkunde, 29 (1937), p. 301

5 ) 湊, 豊島, 垣野: 精密機械, 39 (1973)6, p. 596

6 ) B. C. Ten Horn and $R$. A. Schürmann: Microtecnic, 9(1955), p. 1

7 ) 中山: 精密機械, 40 (1974) 5, p. 409

8 ）白井：機械試験所報告, 第 43 号 (1961), p. 55

9 ) 野呂, 松谷: 昭和 49 年度精機学会秋期大会学術 講演前刷, p. 51

10) 中山：精密㳦械, 26 (1960) 8, p. 482

11) E. K. Henriksen: Trans. ASME, 73(1951), p. 461

12) R. S. HAHN: Trans. ASME, 75 (1953), p. 581

13) 中山, 上野山, 田村: 精密機械, 27(1961) 10, p. 681

14)裟木：「切りくず処理に関するシンポジウム」 (1973), 精機学会切削性専門委員会

15）荒木，谷地：鉄と鋼， 52 (1966) 4, p. 741

16) M. C. Shaw: Machinability, (1965), p. 1, ISI Special Report 94

17)荒木, 谷地：鉄と鋼, 49 (1963) 10, p. 1490

18) $T$. Gladman, $B$. Holmes, and $F$. B. Pickering: JISI, 182 (1970) 2, p. 172

19）たとえば，日本金属学会編：金属便覧，(1971)， p. 696 [丸善] 